\title{
FAKTOR PENYEBAB KESULITAN BELAJAR BAHASA JEPANG MAHASISWA TAHUN MASUK 2018 KELAS INTERNATIONAL PROGRAM STUDI PENDIDIKAN BAHASA INGGRIS UNP
}

\author{
Ricky Eriawan ${ }^{1}$, Meira Anggia Putri ${ }^{2}$ \\ ${ }^{1}$ (Mahasiswa Pendidikan Bahasa Jepang, Bahasa dan Sastra Inggris, Fakultas Bahasa dan \\ Seni, Universitas Negeri Padang), Jl. Prof. Dr. Hamka Air Tawar, Padang 25131 \\ ${ }^{2}$ (Dosen Pendidikan Bahasa Jepang, Bahasa dan Sastra Inggris, Fakultas Bahasa dan Seni, \\ Universitas Negeri Padang), Jl. Prof. Dr. Hamka Air Tawar, Padang 25131 \\ Email Penulis: rickyeriawan71@gmail.com
}

\begin{tabular}{ll}
\hline Sejarah Artikel \\
\hline Submit $\quad: 2020-10-15$ \\
Diterima $:$ :202-10-19 \\
Diterbitkan : $2020-12-11$
\end{tabular}

Kata Kunci:
kesulitan belajar, bahasa
Jepang, mahasiswa kelas
international program studi
pendidikan bahasa Inggris.

\begin{abstract}
The objectives of this study are: (1) To describe the internal factors that cause difficulties for students in learning Japanese (2) To describe the eksternal factors that cause difficulties for students in learning Japanese. This research is a quantitative descriptive study. The population used in the study was 25 students. The sample used in this study is the entire population. The data collection technique in this study used a questionnaire and was guided by the likert scale. While the data analysis technique used is descriptive with a percentage. The results of this study were obtained. (1) The internal factors: the interest indicator by $51 \%$ is in "medium" category. This means that this indicator has a moderate impact in causing difficulty in learning Japanese for students. The attitude-toward-learning indicator by $48 \%$ is in "medium" category. This means that this indicator has a moderate impact in causing difficulty in learning Japanese for students. The health indicator by $41,2 \%$ is in "medium" category. This means that this indicator has a moderate impact in causing difficulty in learning Japanese for students. (2) The external factors: community indicator by $54,13 \%$ is in "medium" category. This means that this indicator has a moderate impact in causing difficulty in learning Japanese for students. The family indicator by $50,4 \%$ is in "medium" category. This means that this indicator has a moderate impact in causing difficulty in learning Japanese for students. The campuss indicator by $47,73 \%$ is in "medium" category. This means that this indicator has a moderate impact in causing difficulty in learning Japanese for students.
\end{abstract}

\footnotetext{
${ }^{1}$ Mahasiswa Prodi Pendidikan Bahasa Jepang FBS UNP lulus pada tanggal 26 Oktober 2020

${ }^{2}$ Dosen Prodi Pendidikan Bahasa Jepang FBS UNP
} 


\section{PENDAHULUAN}

Pendidikan adalah salah satu faktor terpenting dalam memajukan kesejahteraan di Indonesia. Menurut UU No.20 Tahun 2003 tentang sistem pendidikan nasional pada bab I pasal 2 mengatakan bahwa, pendidikan nasional adalah pendidikan yang berlandaskan Pancasila dan Undang-Undang Dasar Negara Republik Indonesia Tahun 1945 yang berakar pada kebudayaan nasional, nilai-nilai agama dan tanggap terhadap tuntutan perubahan. Mempelajari suatu hal akan menambah wawasan dan dapat menjadikan hal tersebut bermanfaat. Dalam mengembangkan potensi peserta didik harus mengembangkannya dengan mempelajarinya. Namun dalam proses pelaksanaan pendidikan sering terjadi kendala dalam proses pembelajaran. Kendala tersebut dapat berpengaruh jika tidak diketahui permasalahannya.

Permasalahan dalam proses pembelajaran dapat mengakibatkan peserta didik tidak dapat mengikuti pembelajaran dengan baik. Salah satu permasalahannya yaitu mengenai kesulitan belajar bagi peserta didik. Sugihartono (2013:149) Kesulitan belajar adalah suatu gejala yang ditandai dengan adanya prestasi belajar yang rendah pada peserta didik. Kesulitan belajar dapat terjadi apabila kemampuan peserta didik berada dibawah batasan normal yang telah ditetapkan. Peserta didik mengalami kesulitan belajar dipengaruhi oleh beberapa faktor. Faktor tersebut yaitu faktor internal dan eksternal.

Sugihartono (2013:155) mengungkapkan faktor internal yang dapat mempengaruhi kesulitan belajar meliputi: minat dan motivasi, kemampuan mengingat, kemampuan berfikir, perasaan dan percaya diri, kematangan untuk belajar, usia, kebiasaan dalam belajar, jenis kelamin, kemampuan mengingat dan kemampuan pengindraan. Sedangkan faktor ekternal meliputi: fasilitas atau instrumen, baik berupa software maupun hardware serta lingkungan. Ada banyak aspek yang menyebabkan peserta didik kesulitan dalam pembelajaran, terlebih dalam mempelajari bahasa.

Bahasa adalah salah satu faktor terpenting dalam menyampaikan informasi, gagasan, pikiran, pendapat, maupun perasaan seseorang untuk dapat berkomunikasi dengan orang lain. Dengan pemahaman bahasa yang baik maka penyampaian makna dari bahasa tersebut dapat diterima baik oleh orang lain. Bahasa adalah modal utama 
kita dalam berkomunikasi. Selain itu, bahasa juga dapat menjadi pemersatu bangsa. Bangsa Indonesia banyak mempelajari bahasa asing, salah satu dari bahasa asing yang dipelajari tersebut adalah bahasa Jepang.

Bahasa Jepang adalah salah satu bahasa asing yang dipelajari di Indonesia. Sebagai salah satu negara yang berhubungan baik dengan negara indonesia, bahasa Jepang sebaiknya kita pelajari untuk menunjang komunikasi satu sama lain. Bahasa Jepang juga merupakan mata kuliah yang wajib dipelajari oleh mahasiswa tahun masuk 2018 kelas international prodi pendidikan bahasa Inggris UNP. Pada pembelajarannya mahasiswa dituntut untuk menguasai pengetahuan dasar berbahasa, keterampilan berbahasa, dan menerapkan pendidikan bahasa yang mengikuti perkembangan IPTEK. Namun dalam perkembangannya mahasiswa masih kesulitan dalam mempelajarinya.

Berdasarkan wawancara yang peneliti lakukan dengan Aty sensei selaku pengajar mata kuliah bahasa Jepang beliau mengungkapkan bahwa sebagian besar mahasiswa tahun masuk 2018 kelas international prodi pendidikan bahasa Inggris UNP belum pernah mempelajari bahasa Jepang. Mereka berpendapat bahwa sewaktu di bangku SMA tidak semua sekolah yang menjadikan bahasa Jepang sebagai mata pelajaran. Hal ini menyebabkan tidak semua mahasiswa memiliki pengetahuan dasar tentang bahasa Jepang tersebut. Sehingga tidak sedikit mahasiswa yang mengeluhkan bahwa mereka mengalami kesulitan ketika mempelajari bahasa Jepang.

Berdasarkan uraian permasalahan di atas peneliti bermaksud melakukan penelitian untuk mendeskripsikan faktor-faktor yang menjadi penyebab kesulitan mahasiswa dalam mengikuti perkuliahan bahasa Jepang. Data yang diperoleh nantinya akan dianalisis untuk mengetahui permasalahan kesulitan tersebut. Selain itu, Belum ada dokumentasi penyebab kesulitan belajar bahasa Jepang di kelas international prodi pendidikan bahasa Inggris UNP.

Berdasarkan latar belakang di atas maka peneliti bermaksud mengadakan penelitian dengan judul "Faktor Penyebab Kesulitan Belajar Bahasa Jepang Mahasiswa Tahun Masuk 2018 Kelas International Program Studi Pendidikan Bahasa Inggris UNP" 
Tujuan dari penelitian ini adalah untuk mendeskripsikan faktor internal dan eksternal yang menyebabkan kesulitan belajar mahasiswa dalam mengikuti perkuliahan bahasa Jepang. Manfaat penelitian ini diharapkan berguna sebagai salah satu sumber informasi terkait faktor-faktor yang menjadi penyebab kesulitan belajar, khususnya bahasa Jepang. Juga sebagai bahan rujukan bagi peneliti selanjutnya mengenai faktor penyebab kesulitan belajar dan kajian dalam topik yang sama dengan penelitian ini.

\section{METODE PENELITIAN}

Jenis penelitian ini adalah penelitian kuantitatif dengan pendekatan deskriptif. Populasi pada penelitian ini adalah mahasiswa tahun masuk 2018 kelas international prodi Pendidikan Bahasa Inggris UNP yang terdiri dari 1 kelas dan berjumlah 25 mahasiswa. Sedangkan Teknik pengambilan sampel yang digunakan adalah teknik total sampling. Variabel yang digunakan dalam penelitian ini adalah variabel terkait dengan faktor kesulitan belajar yang dialami oleh mahasiswa tahun masuk 2018 kelas international prodi pendidikan bahasa Inggris UNP. Data dalam penelitian adalah hasil angket. Pada penelitian ini, yang menjadi instrumen penelitian adalah kuesioner (angket). Menurut Sugiyono (2016:142) kuesioner (angket) adalah teknik pengumpulan data yang digunakan dengan cara memberikan seperangkat pertanyaan atau pernyataan kepada responden penelitian. Penelitian ini menggunakan validitas isi. Validitas ini dilakukan dengan Expert Judgement yaitu setiap item pernyataan dalam instrumen dikonsultasikan oleh ahli evaluasi yang nantinya dimintai pendapatnya tentang instrumen yang digunakan untuk mempertimbangkan layak tidaknya instrumen tersebut. Pada penelitian ini reliabilitas yang dilakukan adalah reliabilitas dengan rumus alpha cronbarch. Nantinya teknik pengumpulan data dalam penelitian ini adalah dengan menyebarkan angket terkait dengan fokus penelitian. Angket ini akan disebarkan kepada reponden yaitu yang berjumlah 25 mahasiswa. Pernyataan yang diberikan yaitu sebanyak 20 pernyataan. Pengumpulan data dilakukan dengan cara menyebarkan angket pada mahasiswa dengan menggunakan google form kemudian menghitung data hasil angket dengan rumus yang berpatokan pada likert. Setelah itu menentukan interval penilaiannya kemudian diinterpretasikan. 


\section{HASIL DAN PEMBAHASAN \\ Temuan Penelitian}

Berikut ini disajikan deskripsi data yang diperoleh dalam penelitian. Penelitian ini mempunyai dua sub variabel yaitu faktor penyebab kesulitan belajar mahasiswa ditinjau dari faktor internal dan eksternal. Dibawah ini adalah hasil skor persentase dari faktor internal dan eksternal:

\section{Tabel.1}

\section{Hasil analisis data}

\begin{tabular}{llll}
\hline No & Keterangan & Skor Persentase \% & \\
\hline & & & $\begin{array}{l}\text { Skor persentase yang } \\
\text { didapatkan adalah } \\
46,73 \% \text { dari } 100 \% \text { yang } \\
\text { ada di indikator faktor } \\
\text { internal. }\end{array}$ \\
\hline & Faktor Internal & $46,73 \%$ dari $100 \%$ & $\begin{array}{l}\text { Skor persentase yang } \\
\text { didapatkan adalah } \\
50,75 \% \text { dari } 100 \% \text { yang } \\
\text { ada di indikator faktor } \\
\text { eksternal. }\end{array}$ \\
\hline
\end{tabular}

Berdasarkan tabel diatas diketahui faktor internal penyebab kesulitan belajar bahasa Jepang adalah $46,73 \%$ berada pada kategori "Sedang". Sedangkan faktor eksternal $50,75 \%$ berada pada kategori "Sedang". Berikut disajikan hasil dari deskripsi data berdasarkan faktor internal dan eksternal:

\section{a. Faktor internal penyebab kesulitan belajar bahasa Jepang}

Terdapat 3 indikator dalam faktor internal kesulitan belajar bahasa Jepang. Indikator tersebut adalah sikap terhadap belajar, minat dan kesehatan. Berikut ini adalah hasil dari analisis data dari ketiga indikator terbebut. 
Tabel.2

Analisis data faktor internal

\begin{tabular}{|c|c|c|c|}
\hline & Indikator & $\begin{array}{c}\text { Skor Persen } \\
(\%)\end{array}$ & Keterangan \\
\hline \multirow{4}{*}{$\begin{array}{l}\text { Faktor } \\
\text { Internal }\end{array}$} & Sikap terhadap belajar & $48 \%$ & Rendah \\
\hline & Minat & $51 \%$ & Rendah \\
\hline & Kesehatan & $41,2 \%$ & Rendah \\
\hline & Rata-Rata & $46,73 \%$ & Rendah \\
\hline
\end{tabular}

Berdasarkan data yang ditemukan dalam penelitian ini, ditinjau dari faktor internal sebesar $46,73 \%$ berada pada kategori "Rendah". Artinya faktor internal ini berdampak "Rendah" dalam menyebabkan kesulitan belajar bahasa Jepang mahasiswa. Dari hasil penelitian di atas guna mempermudah dalam melihat faktor penyebab kesulitan belajar bahasa Jepang dari faktor internal maka hasil nilai skor persen dari masing-masing indikator akan disajikan dalam bentuk grafik :

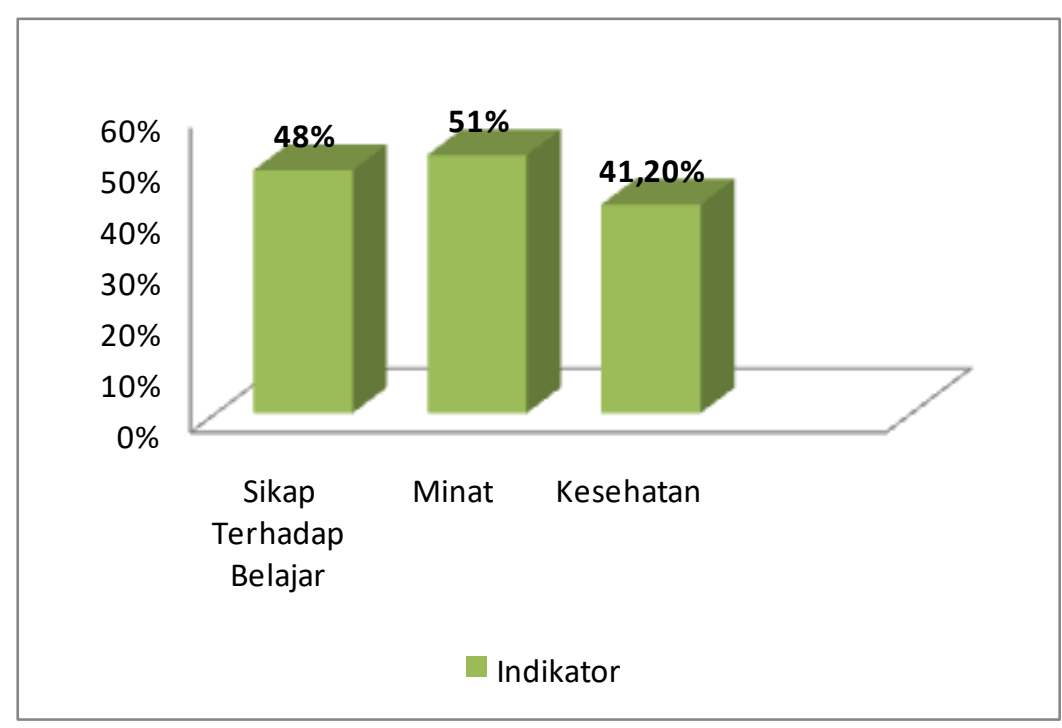

\section{Gambar.1}

\section{Diagram batang faktor internal kesulitan belajar bahasa Jepang}

Dari diagram di atas, diketahui bahwa dari faktor internal kesulitan belajar bahasa Jepang, indikator minat mendominasi dengan nilai persen $51 \%$ berada pada 
kategori "Rendah", diikuti dengan indikator sikap dalam belajar $48 \%$ berada pada kategori "Rendah", selanjutnya indikator kesehatan dengan skor persen 41,20\% berada pada kategori "Rendah". Dari hasil persentase faktor internal tersebut indikator minat adalah indikator yang paling mempengaruhi karena indikator tersebut merupakan indikator dengan persentase paling tinggi dibandingkan dengan kedua indikator lainnya.

\section{b. Faktor eksternal penyebab kesulitan belajar bahasa Jepang}

Terdapat 3 indikator dalam faktor eksternal kesulitan belajar bahasa Jepang. Indikator tersebut adalah lingkungan keluarga, lingkungan kampus dan lingkungan masyarakat. Berikut ini adalah hasil dari analisis data dari ketiga indikator terbebut.

Tabel.3

\begin{tabular}{|c|c|c|c|}
\hline \multirow{5}{*}{$\begin{array}{c}\text { Faktor } \\
\text { Eksternal }\end{array}$} & Indikator & Skor Persen (\%) & Keterangan \\
\hline & Lingkungan keluarga & $50,4 \%$ & Rendah \\
\hline & Lingkungan kampus & $47,73 \%$ & Rendah \\
\hline & Lingkungan masyaraka & 54,13 & Rendah \\
\hline & Rata-I & $50,75 \%$ & Rendah \\
\hline
\end{tabular}

Berdasarkan data yang ditemukan dalam penelitian ini, ditinjau dari faktor eksternal sebesar $50,75 \%$ berada pada kategori "Rendah". Artinya faktor eksternal ini berdampak "Rendah" dalam menyebabkan kesulitan belajar bahasa Jepang mahasiswa. Dari hasil penelitian di atas guna mempermudah dalam melihat faktor penyebab kesulitan belajar bahasa Jepang dari faktor eksternal, hasil nilai skor persen dari masing-masing indikator akan disajikan dalam bentuk grafik : 


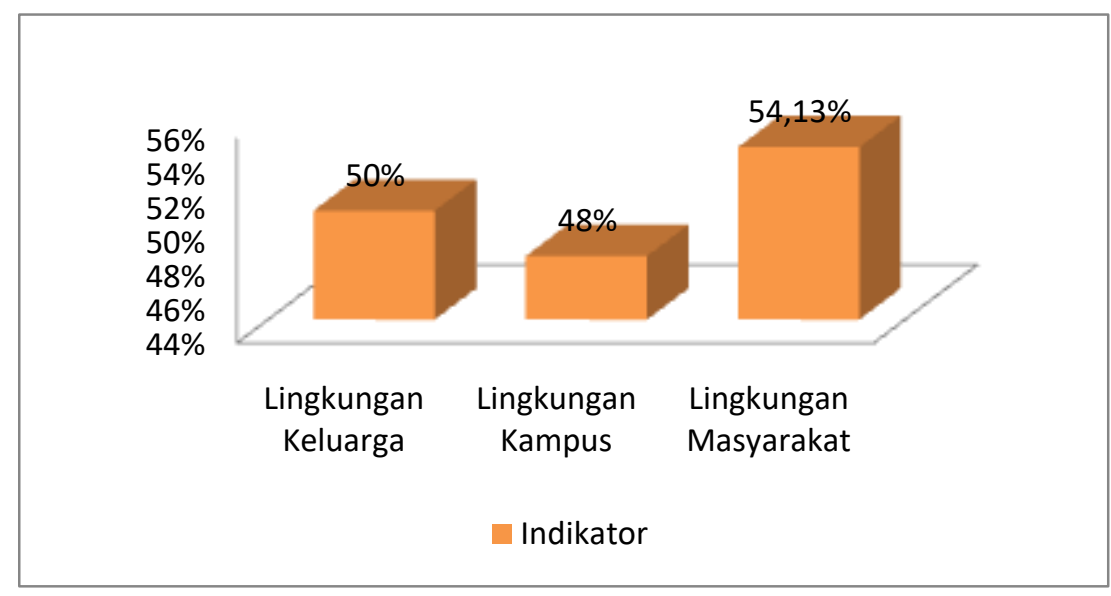

\section{Gambar.2}

\section{Diagram batang faktor internal kesulitan belajar bahasa Jepang}

Dari diagram di atas, diketahui bahwa dari faktor eksternal kesulitan belajar bahasa Jepang, indikator lingkungan masyarakat mendominasi dengan nilai persen $54,13 \%$ berada pada kategori "Rendah", diikuti dengan indikator lingkungan keluarga 50,4\% berada pada kategori "Rendah", selanjutnya indikator lingkungan kampus dengan skor persen $47,73 \%$ berada pada kategori "Rendah". Dari hasil persentase faktor eksternal tersebut indikator lingkungan masyarakat adalah indikator yang paling mempengaruhi karena indikator tersebut merupakan indikator dengan persentase paling tinggi dibandingkan dengan kedua indikator lainnya. Berdasarkan deskripsi data di atas maka peneliti dapat menganalisis faktor penyebab kesulitan belajar bahasa Jepang mahasiswa sebagai berikut:

\section{Tabel.4}

Tabel Hasil Analisis Angket Mahasiswa

\begin{tabular}{|c|c|c|c|}
\hline Aspek & Indikator & Skor persentase $(\%)$ & Kriteria \\
\hline \multirow{3}{*}{ Faktor Internal } & Sikap terhadap belajar & $48 \%$ & Rendah \\
\hline & Minat & $51 \%$ & Rendah \\
\hline & Kesehatan & $41,2 \%$ & Rendah \\
\hline Faktor & Lingkungan keluarga & $50,4 \%$ & Rendah \\
\hline
\end{tabular}




\begin{tabular}{clcc}
\hline \multirow{2}{*}{ Eksternal } & Lingkungan kampus & $47,73 \%$ & Rendah \\
\cline { 2 - 4 } & Lingkungan masyarakat & $54,13 \%$ & Rendah \\
\hline
\end{tabular}

Berdasarkan tabel di atas interpretasi data dari faktor internal adalah: indikator sikap terhadap belajar dengan skor persen $48 \%$, yang berdasarkan kategorinya termasuk dalam kategori "Rendah". Artinya pada indikator ini dampak yang ditimbulkan pada kesulitan belajar bahasa Jepang termasuk dalam kondisi rendah. Indikator minat dengan skor persen $51 \%$ yang berdasarkan kategorinya termasuk dalam kategori "Rendah". Artinya pada indikator ini dampak yang ditimbulkan pada kesulitan belajar bahasa Jepang termasuk dalam kondisi rendah. Indikator kesehatan dengan skor persen $41,2 \%$, yang berdasarkan kategorinya termasuk dalam kategori "Rendah". Artinya pada indikator ini dampak yang ditimbulkan pada kesulitan belajar bahasa Jepang termasuk dalam kondisi rendah. Jadi, didapatkan bahwa dalam faktor internal tersebut indikator minat adalah indikator dengan persentase tertinggi dalam menyebabkan kesulitan belajar bahasa Jepang jika dibandingkan indikator sikap terhadap belajar dan indikator minat.

Berdasarkan tabel di atas interpretasi data dari faktor eksternal adalah: indikator lingkungan keluarga dengan skor persen 50,4\%, yang berdasarkan kategorinya termasuk dalam kategori "Rendah". Artinya pada indikator ini dampak yang ditimbulkan pada kesulitan belajar bahasa Jepang termasuk dalam kondisi rendah. Indikator lingkungan kampus dengan skor persen 47,73\%, yang berdasarkan kategorinya termasuk dalam kategori "Rendah". Artinya pada indikator ini dampak yang ditimbulkan pada kesulitan belajar bahasa Jepang termasuk dalam kondisi rendah. Indikator lingkungan masyarakat dengan skor persen 54,13\%, yang berdasarkan kategorinya termasuk dalam kategori "Rendah". Artinya pada indikator ini dampak yang ditimbulkan pada kesulitan belajar bahasa Jepang termasuk dalam kondisi rendah. Jadi, didapatkan bahwa dalam faktor eksternal tersebut indikator lingkungan masyarakat adalah indikator dengan persentase tertinggi dalam menyebabkan kesulitan belajar bahasa Jepang jika dibandingkan indikator lingkungan kampus dan indikator lingkungan keluarga. 


\section{Pembahasan}

Dari hasil analisis data penelitian di atas, peneliti menemukan faktor penyebab kesulitan yang ditinjau dari faktor internal dan eksternal. Pembahasan dari hasil penelitian ini nantinya dimaksudkan untuk menjawab pertanyaan penelitian yang telah dirumuskan sebelumnya.

Berdasarkan persentase hasil penelitian, faktor internal penyebab kesulitan belajar diketahui indikator sikap terhadap belajar sebesar $48 \%$ berada pada kategori "Rendah", diinterpretasikan bahwa pada indikator ini dampak yang ditimbulkan pada kesulitan belajar bahasa Jepang termasuk dalam kondisi rendah. Indikator minat sebesar $51 \%$ berada pada kategori "Rendah", diinterpretasikan bahwa pada indikator ini dampak yang ditimbulkan pada kesulitan belajar bahasa Jepang termasuk dalam kondisi rendah. Indikator kesehatan sebesar $41,2 \%$ berada pada indikator "Rendah", diinterpretasikan bahwa pada indikator ini dampak yang ditimbulkan pada kesulitan belajar bahasa Jepang termasuk dalam kondisi rendah. Meskipun ketiga indikator tersebut berada pada kategori rendah indikator minat merupakan hal yang dominan menyebabkan kesulitan belajar bahasa Jepang. Hal itu dibuktikan dengan persentase yang didapatkan oleh indikator minat merupakan indikator dengan persentase tertinggi. Berdasarkan hasil tersebut dapat disimpulkan bahwa faktor internal penyebab kesulitan belajar mahasiswa berada pada indikator minat. Hal ini dapat dikatakan bahwa minat mahasiswa terhadap pelajaran bahasa Jepang rendah dan paling tinggi menyebabkan kesulitan jika dibandingkan indikator sikap terhadap belajar dan indikator kesehatan.

Sedangkan persentase hasil penelitian, faktor eksternal penyebab kesulitan belajar diketahui indikator lingkungan keluarga sebesar $50,4 \%$ berada pada kategori "Rendah", diinterpretasikan bahwa pada indikator ini dampak yang ditimbulkan pada kesulitan belajar bahasa Jepang termasuk dalam kondisi rendah. Indikator lingkungan kampus sebesar $47,73 \%$ berada pada kategori "Rendah", diinterpretasikan bahwa pada indikator ini dampak yang ditimbulkan pada kesulitan belajar bahasa Jepang termasuk dalam kondisi rendah. Indikator lingkungan masyarakat sebesar 54,13\% berada pada kategori "Rendah", diinterpretasikan bahwa 
pada indikator ini dampak yang ditimbulkan pada kesulitan belajar bahasa Jepang termasuk dalam kondisi rendah. Meskipun ketiga indikator tersebut berada pada kategori rendah indikator lingkungan masyarakat merupakan hal yang dominan menyebabkan kesulitan belajar bahasa Jepang. Hal itu dibuktikan dengan persentase yang didapatkan oleh indikator lingkungan masyarakat merupakan indikator dengan persentase tertinggi. Berdasarkan hasil tersebut dapat disimpulkan bahwa faktor eksternal penyebab kesulitan belajar mahasiswa berada pada indikator lingkungan masyarakat.

\section{KESIMPULAN}

Dari pembahasan yang telah diuraikan di atas, peneliti dapat menarik kesimpulan tentang faktor penyebab kesulitan belajar bahasa Jepang mahasiswa adalah sebagai berikut:

1. Faktor penyebab kesulitan belajar bahasa Jepang mahasiswa tahun masuk 2018 kelas international program studi pendidikan bahasa Inggris UNP, ditinjau dari faktor internal sebesar 46,73\% yang termasuk dalam kategori "Rendah", diinterpretasikan bahwa pada fakror internal ini dampak yang ditimbulkan pada kesulitan belajar bahasa Jepang termasuk dalam kondisi rendah. Dengan indikator sikap dalam belajar $48 \%$ berada pada kategori "Rendah", diinterpretasikan bahwa pada indikator ini dampak yang ditimbulkan pada kesulitan belajar bahasa Jepang termasuk dalam kondisi rendah. Indikator minat 51\% berada pada kategori "Rendah", diinterpretasikan bahwa pada indikator ini dampak yang ditimbulkan pada kesulitan belajar bahasa Jepang termasuk dalam kondisi rendah. Dan indikator kesehatan 41,2\% berada pada kategori "Rendah", diinterpretasikan bahwa pada 
indikator ini dampak yang ditimbulkan pada kesulitan belajar bahasa Jepang termasuk dalam kondisi rendah.

2. Faktor penyebab kesulitan belajar bahasa Jepang mahasiswa tahun masuk 2018 kelas international program studi pendidikan bahasa Inggris UNP, ditinjau dari faktor eksternal sebesar 50,75\% berada pada kategori "Rendah", diinterpretasikan bahwa pada faktor eksternal ini dampak yang ditimbulkan pada kesulitan belajar bahasa Jepang termasuk dalam kondisi rendah. Dengan indikator lingkungan keluarga 50,4\% berada pada kategori "Rendah", diinterpretasikan bahwa pada indikator ini dampak yang ditimbulkan pada kesulitan belajar bahasa Jepang termasuk dalam kondisi rendah. Indikator lingkungan kampus $47,73 \%$ berada pada kategori "Rendah", diinterpretasikan bahwa pada indikator ini dampak yang ditimbulkan pada kesulitan belajar bahasa Jepang termasuk dalam kondisi rendah. Dan indikator lingkungan masyarakat $54,13 \%$ berada pada kategori "Rendah", diinterpretasikan bahwa pada indikator ini dampak yang ditimbulkan pada kesulitan belajar bahasa Jepang termasuk dalam kondisi rendah.

\section{REFERENSI}

Arikunto, Suharsimi. 2006. Prosedur Penelitian Suatu Pendekatan Praktek, Jakarta: Rineka Cipta.

2010. Prosedur Penelitian Suatu Pendekatan Praktik. Jakarta: PT. Rineka Cipta.

Diyah Istiqomah, dkk.2015. Analisis Kesulitan Belajar Bahasa Jepang Siswa SMK Bagimu Negeriku Semarang. Jurnal. CHI'E 4 (1). 
Gusnovita, Ira. Delvi Wahyuni, dan Meira Anggia Putri. 2018. Kecemasan Berbicara Pada Mahasiswa Semester V Program Studi Pendidikan Bahasa Jepang di Universitas Negeri Padang. Jurnal. Omiyage. Vol.1, No.1, Oktober 2020

Kurniawan, Zuhrian Hendra. 2015. Faktor Penyebab Kesulitan Belajar Bahasa Jepang Siswa SMA Negeri 15 Semarang. Skripsi. Semarang. UNNES.

Meter, Gede. Ni Putu Listya Dewi Lestari. I Gusti Agung Oka Negara. 2015. Analisis Kesulitan-Kesulitan Belajar Bahasa Indonesia Siswa Kelas IV Dalam Implementasi Kurikulum 2013 Di SD Piloting Se-Kabupaten Gianyar. Jurnal. PGSD. Vol.3, No.1, September 2020.

Putri, Meira Anggia. 2019. Faktor Internal dan Eksternal Penyebab Masalah Pembelajaran Kalimat Pasif Bahasa Jepang Pada Mahasiswa Tingkat 3 Prodi Pendidikan Bahasa Jepang Universitas Negeri Padang. Jurnal. Minasai. 239-254, September 2020

Slameto. 2015. Belajar \& Faktor-Faktor yang Mempengaruhinya. Jakarta: Rineka Cipta.

Sugihartono, dkk. 2013. Psikologi Pendidikan. Yogyakarta: UNY Press.

Sugiyono. 2016. Metode Penelitian Kuantitatif, Kualitatif, dan R\&D. Bandung: Alfabeta.

2013. Metode Penelitian Kuantitatif, Kualitatif, dan R\&D. Bandung: Alfabeta.

UU No.20 Tahun 2003 Tentang Sistem Pendidikan. 